\title{
A Comparative Study on the Effect of the Substitute in Some of the Game Situations in the Africa Cup of Nations and the European Soccer Championship
}

\author{
Hesham Mohamed Ahmed Hamdoun ${ }^{1}$ \\ ${ }^{1}$ Assistant Professor at the Sport Games Training Department, Faculty of Sport Education for Men at Abu Qir, Alexandria \\ University.
}

\begin{abstract}
Soccer has many and various situations whether offensive or defensive, and almost all the games have some players substituted in different times during the match, the substitute has his predetermined duties according to the match's situation and result, or to maintain the result as possible. Most of the players do their role and become the key players in many hard offensive and defensive situations as they have enough experience and high technical level, taking into consideration that the substitute's negative performance would be reflected on the game's result.
\end{abstract}

The study is important because it aims at determining the role of the substitute in the different game situations in the African and European soccer championships, in order to take advantage of this analytical study in the training process.

By reviewing the previous literature and through the researcher's work in the field of soccer training, it was clear that there is a lack in the literature and research concerned with the role of the substitute, and by following the substitute in the African and European soccer championships, we would find that the substitute was the main reason that the Egyptian team won the 2010 Africa Cup of Nations and the Spanish team won the 2012 European Soccer Championship. It was obvious in the game of Egypt vs. Ghana in the 2010 Africa Cup of Nations when Nagy Gedo entered the game and scored the goal that won the championship, this also happened in the final of the 2012 European Soccer Championship between Spain and Italy when Spain won 4-0, with two substitutes, Fernando Torres and Juan Mata scoring two goals.

Introduction and research problem:

Ooccer has many and various situations whether offensive or defensive, and almost all the games have some players substituted in different times during the match, the substitute has his predetermined duties according to the match's situation and result, or to maintain the result as possible. Most of the players do their role and become the key players in many hard offensive and defensive situations as they have enough experience and high technical level, taking into consideration that the substitute's negative performance would be reflected on the game's result.

Mufty Ibrahim (1994), Mahmoud Bassiouny (1994), Hanafy Mokhtar (1995), Bernadette Woods \& Joanne Thatcher (2009), Bret Myers (2011) Moussa Ibrahim (2013), and Bradley et al (2014) all agree that the substitution during the game is a precise process and requires featuring players who have experience, intelligence and wisdom in certain times during the match, in order to keep the result of the game, or to equalize, or due to the decreased physical and technical level of the main player, the substitution may take place due to an injury of a player or for tactical reasons to change the plan. (3:67), (1:34), (2:54), (1:453), (2:2), (4:29), (4:416)

The study is important because it aims at determining the role of the substitute in the different game situations in the African and European soccer championships, in order to take advantage of this analytical study in the training process.

By reviewing the previous literature and through the researcher's work in the field of soccer training, it was clear that there is a lack in the literature and research concerned with the role of the substitute, and by following the substitute in the African and European soccer championships, we would find that the substitute was the main reason that the Egyptian team won the 2010 Africa Cup of Nations and the Spanish team won the 2012 European Soccer Championship. It was obvious in the 
game of Egypt vs. Ghana in the 2010 Africa Cup of Nations when Nagy Gedo entered the game and scored the goal that won the championship, this also happened in the final of the 2012 European Soccer Championship between Spain and Italy when Spain won 4-0, with two substitutes, Fernando Torres and Juan Mata scoring two goals.

\section{Aim of the research:}

Identifying the differences between the 2010 and 2012 editions of the Africa Cup of Nations and the 2008 and 2012 editions of the European Soccer Championship regarding the effect of the substitute on some of the game situations through the following:

1- Identifying the effect of the substitute on the technical performance in the African and European Soccer championships.

2- Identifying the effect of the substitute according to the goal of involving him in the African and European Soccer championships.

3- Identifying the effect of the substitute on the game in the African and European Soccer championships.

4- Identifying the effect of the substitute on the result of the game and its target in the African and European Soccer championships.

5- Identifying the effect of the substitute's entry according to the variables of the opposing team's performance in the match in the African and European Soccer championships.

\section{Research questions:}

1- Are there statistically significant differences between the 2010 and 2012 editions of the African and European soccer championships in the effect of the substitute in some situations of the match?

2- Is there an effect of the substitute on the technical performance in the 2010 and 2012 editions of the African and European soccer championships?

3- Is there an effect of the substitute according to the goal of involving him in the African and European soccer championships?

4- Is there an effect of the substitute on the game in the African and European soccer championships?

5- Is there an effect of the substitute on the result of the game and its target in the African and European soccer championships?
6- Is there an effect of the substitute's entry according to the variables of the opposing team's performance in the match in the African and European soccer championships?

7- Are there differences between the effect of the substitute in the African and European soccer championships?

\section{Research procedures:}

\section{Research methodology:}

The researcher used the descriptive approach.

\section{Research sample:}

\section{Human domain:}

The bench players of fourteen games in the 2010 and 2012 Africa Cup of Nations and the 2008 and 2012 European Soccer Championship, Attachment (2)

\section{Time domain:}

The researcher conducted the pilot study in the period from 5/9/2012 until $1 / 11 / 2012$ and then conducted the main study in the period from 15/1/2013 until 6/4/2013.

\section{Spatial domain:}

Analysis was conducted in an equipped room at the researcher's residence.

\section{Research tools:}

1. A data registration form, Attachment (1).

2. Experts: (9) experts were selected, Attachment (2).

3. Scientific observation in analyzing the games: studying the variables of some of the game situations for the effect of the substitute by analyzing the data collecting form of the game situations using a computer.

\section{Pilot studies:}

\section{Objectives of the study:}

1- Identifying some of the variables of the game situations for the effect of involving the substitute which will be analyzed during the main study.

2- Confirming the validity of the data collecting form as well as the optimal method of analysis through the registration $\mathrm{CDs}$ and the safety of the devices used in the study. 


\section{Result of the study:}

Some of the important variables of the game situations were determined of the effect of the substitute's entry which will be analyzed in the main study.

\section{Scientific treatments:}

- Validity of the form was calculated by the percentage of consistency of the reviewers. Table (1)

- Reliability of the form was calculated by analyzing one match of the first round of the 2012 Africa Cup of Nations
(Equatorial Guinea Vs. Libya) and one match of the first round of the 2012 European Soccer Championship (Russia Vs. Czech Republic), then the same games were re-analyzed one week later to make sure of the reliability of the results of the games analysis and the data collecting form, the result was shown in Table (2), and this was in the period from 22/10/2012 until 29/10/2012.

\section{Validity of the content:}

Table (1)

The percentage of consistency of the experts on the effect of the variables of the substitute's entry in some game situations ( $\mathrm{N}=9$ experts)

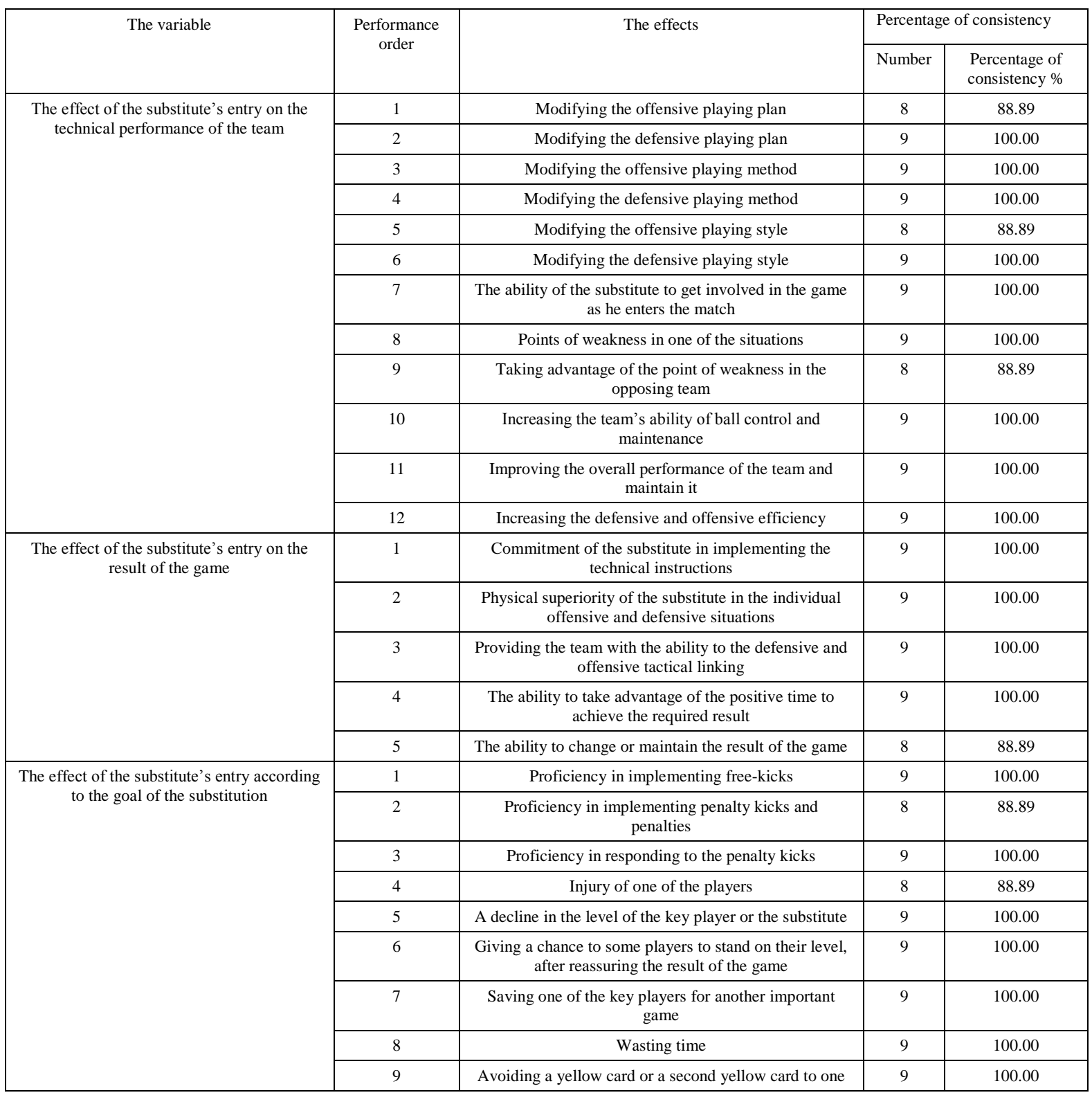




\begin{tabular}{|c|c|c|c|c|}
\hline & & of the players & & \\
\hline \multirow{9}{*}{$\begin{array}{l}\text { The effect of the substitute's entry according } \\
\text { to the variables of the opposing team's } \\
\text { performance in the game }\end{array}$} & 1 & Confusing the players of the opposing team & 9 & 100.00 \\
\hline & 2 & Limiting the ability of a player of the opposing team & 8 & 88.89 \\
\hline & 3 & $\begin{array}{c}\text { Reading the game and disabling the playing keys of the } \\
\text { opposing team }\end{array}$ & 9 & 100.00 \\
\hline & 4 & Forcing the opposing team to change the plan & 9 & 100.00 \\
\hline & 5 & $\begin{array}{l}\text { Forcing the opposing team's coach to change the } \\
\text { situation of one of the special players who has tactical } \\
\text { solutions }\end{array}$ & 8 & 88.89 \\
\hline & 6 & $\begin{array}{l}\text { Making a substitution as a respond to another } \\
\text { substitution for the opposing team }\end{array}$ & 8 & 88.89 \\
\hline & 7 & $\begin{array}{l}\text { The substitute has high fitness so the coach save him } \\
\text { until fatigue appears on the opposing team }\end{array}$ & 8 & 88.89 \\
\hline & 8 & $\begin{array}{l}\text { The substitute has high technical abilities, tactical } \\
\text { solutions and experience so the coach save him until } \\
\text { fatigue appears on the opposing team }\end{array}$ & 9 & 100.00 \\
\hline & 9 & $\begin{array}{l}\text { The ability to change the result of the game due to the } \\
\text { proficiency of that }\end{array}$ & 9 & 100.00 \\
\hline \multirow{4}{*}{$\begin{array}{l}\text { The effect of the substitute's entry on the } \\
\text { result of the game and its aim }\end{array}$} & 1 & The player scores a goal and win & 8 & 88.89 \\
\hline & 2 & The player prevents scoring a goal & 9 & 100.00 \\
\hline & 3 & Making a goal & 8 & 88.89 \\
\hline & 4 & Improving the general ball control & 9 & 100.00 \\
\hline
\end{tabular}

Table (1) shows the percentage of consistency of the the variables and the effects of the substitute's entry on experts on the effect of the variables of the substitute's entry. The percentage of consistency ranged between $(88.89 \%$ and $100 \%)$ and due to the high percentage of consistency on the effects, the researcher has relied on all some of the technical situations in the 2010 and 2012 editions of the Africa Cup of Nations and the 2008 and 2012 editions of the European Soccer Championship.

\section{Reliability coefficient of the form:}

Table (2)

Application and re-application for calculating the reliability of the form of observing the variables of the effect of the substitute's entry, $\mathrm{N}=$ two games (a match of the Africa Cup of Nations for two teams and a match of the European Soccer Championship for two teams)

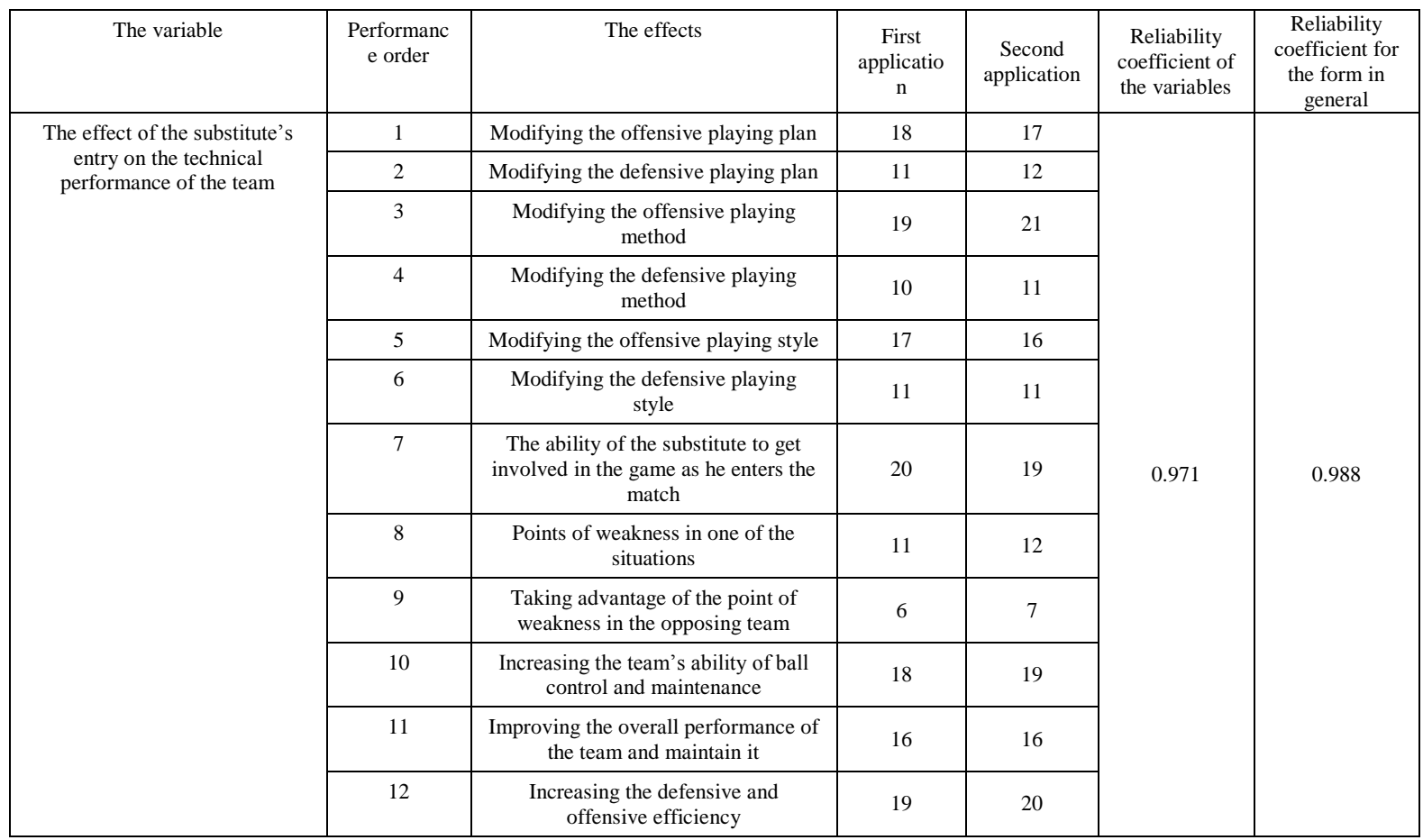




\begin{tabular}{|c|c|c|c|c|c|}
\hline \multirow[t]{5}{*}{$\begin{array}{l}\text { The effect of the substitute's } \\
\text { entry on the result of the game }\end{array}$} & 1 & $\begin{array}{l}\text { Commitment of the substitute in } \\
\text { implementing the technical } \\
\text { instructions }\end{array}$ & 16 & 18 & \multirow[t]{5}{*}{0.978} \\
\hline & 2 & $\begin{array}{c}\text { Physical superiority of the substitute } \\
\text { in the individual offensive and } \\
\text { defensive situations }\end{array}$ & 19 & 17 & \\
\hline & 3 & $\begin{array}{l}\text { Providing the team with the ability to } \\
\text { the defensive and offensive tactical } \\
\text { linking }\end{array}$ & 16 & 18 & \\
\hline & 4 & $\begin{array}{c}\text { The ability to take advantage of the } \\
\text { positive time to achieve the required } \\
\text { result }\end{array}$ & 11 & 10 & \\
\hline & 5 & $\begin{array}{l}\text { The ability to change or maintain the } \\
\text { result of the game }\end{array}$ & 10 & 10 & \\
\hline \multirow{9}{*}{$\begin{array}{l}\text { The effect of the substitute's } \\
\text { entry according to the goal of } \\
\text { the substitution }\end{array}$} & 1 & $\begin{array}{c}\text { Proficiency in implementing free- } \\
\text { kicks }\end{array}$ & 6 & 7 & \multirow[t]{9}{*}{0.960} \\
\hline & 2 & $\begin{array}{l}\text { Proficiency in implementing penalty } \\
\text { kicks and penalties }\end{array}$ & 0 & 1 & \\
\hline & 3 & $\begin{array}{l}\text { Proficiency in responding to the } \\
\text { penalty kicks }\end{array}$ & 0 & 0 & \\
\hline & 4 & Injury of one of the players & 0 & 0 & \\
\hline & 5 & $\begin{array}{l}\text { A decline in the level of the key } \\
\text { player or the substitute }\end{array}$ & 19 & 20 & \\
\hline & 6 & $\begin{array}{l}\text { Giving a chance to some players to } \\
\text { stand on their level, after reassuring } \\
\text { the result of the game }\end{array}$ & 4 & 5 & \\
\hline & 7 & $\begin{array}{l}\text { Saving one of the key players for } \\
\text { another important game }\end{array}$ & 0 & 0 & \\
\hline & 8 & Wasting time & 8 & 9 & \\
\hline & 9 & $\begin{array}{l}\text { Avoiding a yellow card or a second } \\
\text { yellow card to one of the players }\end{array}$ & 5 & 4 & \\
\hline \multirow{9}{*}{$\begin{array}{l}\text { The effect of the substitute's } \\
\text { entry according to the variables } \\
\text { of the opposing team's } \\
\text { performance in the game }\end{array}$} & 1 & $\begin{array}{c}\text { Confusing the players of the } \\
\text { opposing team }\end{array}$ & 15 & 14 & \multirow[t]{9}{*}{0.951} \\
\hline & 2 & $\begin{array}{c}\text { Limiting the ability of a player of the } \\
\text { opposing team }\end{array}$ & 15 & 16 & \\
\hline & 3 & $\begin{array}{l}\text { Reading the game and disabling the } \\
\text { playing keys of the opposing team }\end{array}$ & 14 & 15 & \\
\hline & 4 & $\begin{array}{l}\text { Forcing the opposing team to change } \\
\text { the plan }\end{array}$ & 9 & 10 & \\
\hline & 5 & $\begin{array}{l}\text { Forcing the opposing team's coach to } \\
\text { change the situation of one of the } \\
\text { special players who has tactical } \\
\text { solutions }\end{array}$ & 0 & 1 & \\
\hline & 6 & $\begin{array}{c}\text { Making a substitution as a respond } \\
\text { to another substitution for the } \\
\text { opposing team }\end{array}$ & 14 & 13 & \\
\hline & 7 & $\begin{array}{l}\text { The substitute has high fitness so the } \\
\text { coach save him until fatigue appears } \\
\text { on the opposing team }\end{array}$ & 16 & 15 & \\
\hline & 8 & $\begin{array}{l}\text { The substitute has high technical } \\
\text { abilities, tactical solutions and } \\
\text { experience so the coach save him } \\
\text { until fatigue appears on the opposing } \\
\text { team }\end{array}$ & 16 & 17 & \\
\hline & 9 & $\begin{array}{l}\text { The ability to change the result of the } \\
\text { game due to the proficiency of that }\end{array}$ & 5 & 5 & \\
\hline \multirow{4}{*}{$\begin{array}{l}\text { The effect of the substitute's } \\
\text { entry on the result of the game } \\
\text { and its aim }\end{array}$} & 1 & The player scores a goal and win & 10 & 9 & \multirow[t]{4}{*}{0.937} \\
\hline & 2 & The player prevents scoring a goal & 5 & 6 & \\
\hline & 3 & Making a goal & 1 & 1 & \\
\hline & 4 & Improving the general ball control & 16 & 17 & \\
\hline
\end{tabular}

Table (2) that represents the application and re-application variables of the effect of the substitute's entry showed that for calculating the reliability of the form of observing the the reliability coefficient of the variables ranged between 
(0.937 and 0.978) while the reliability coefficient of the form in general was $(0.988)$, these values are considered high and confirms that the form has the ability to give the same results if re-applied to the same games in the same conditions and using the same means therefore the form is persistent.

\section{Presentation and discussion of the results}

Table (3)

Significance differences between the teams of the 2010 and 2012 editions of the Africa Cup of

Nations and the 2008 and 2012 editions of the European Soccer Championship in the effect of the substitute's entry on the variables of the technical performance of the team

\begin{tabular}{|c|c|c|c|c|c|c|c|c|c|}
\hline \multirow[t]{2}{*}{$\begin{array}{l}\text { The effect of } \\
\text { the substitute }\end{array}$} & & \multirow[t]{2}{*}{ Playing situations } & \multicolumn{2}{|c|}{$\begin{array}{c}\text { Africa Cup of } \\
\text { Nations } \\
\mathrm{N}=28\end{array}$} & \multicolumn{2}{|c|}{$\begin{array}{c}\text { European } \\
\text { Soccer } \\
\text { Championship } \\
\mathrm{N}=28\end{array}$} & \multirow[t]{2}{*}{$\begin{array}{c}\text { Difference } \\
\text { between } \\
\text { means }\end{array}$} & \multirow[t]{2}{*}{$\begin{array}{l}\text { Calcu } \\
\text { lated } \\
(\mathrm{t}) \\
\text { value }\end{array}$} & \multirow[t]{2}{*}{$\begin{array}{c}\text { Percentag } \\
\text { e of } \\
\text { difference } \\
\text { s } \%\end{array}$} \\
\hline & & & $\mathrm{X}$ & $\pm \mathrm{P}$ & $\mathrm{X}$ & $\pm \mathrm{P}$ & & & \\
\hline \multirow{11}{*}{$\begin{array}{l}\text { The effect of } \\
\text { the substitute's } \\
\text { entry on the } \\
\text { technical } \\
\text { performance of } \\
\text { the team }\end{array}$} & 1 & Modifying the offensive playing plan & 3.54 & 1.26 & 3.96 & 0.92 & -0.34 & -1.45 & -12.12 \\
\hline & 2 & Modifying the defensive playing plan & 2.75 & 1.14 & 2.32 & 1.16 & 0.43 & 1.39 & 15.58 \\
\hline & 3 & Modifying the offensive playing method & 3.54 & 1.45 & 4.04 & 0.84 & -0.50 & -1.58 & -14.14 \\
\hline & 4 & Modifying the defensive playing method & 2.93 & 1.12 & 2.46 & 0.79 & 0.46 & 1.79 & 15.85 \\
\hline & 5 & Modifying the offensive playing style & 3.57 & 1.35 & 3.93 & 0.81 & -0.36 & -1.20 & -10.00 \\
\hline & 6 & Modifying the defensive playing style & 2.61 & 1.26 & 2.36 & 1.06 & 0.25 & 0.80 & 9.59 \\
\hline & 7 & $\begin{array}{l}\text { The ability of the substitute to get involved in the } \\
\text { game as he enters the match }\end{array}$ & 3.36 & 1.59 & 4.64 & 0.73 & -1.29 & $-\overline{-} \cdot 38^{*}$ & -38.30 \\
\hline & 9 & $\begin{array}{l}\text { Taking advantage of the point of weakness in the } \\
\text { opposing team }\end{array}$ & 2.50 & 1.60 & 2.04 & 1.55 & 0.46 & 1.10 & 18.57 \\
\hline & 10 & $\begin{array}{c}\text { Increasing the team's ability of ball control and } \\
\text { maintenance }\end{array}$ & 3.39 & 1.45 & 4.00 & 0.94 & -0.61 & -1.86 & -17.89 \\
\hline & 11 & $\begin{array}{c}\text { Improving the overall performance of the team } \\
\text { and maintain it }\end{array}$ & 3.29 & 1.56 & 3.93 & 0.90 & -0.64 & -1.89 & -19.57 \\
\hline & 12 & Increasing the defensive and offensive efficiency & 3.36 & 1.64 & 3.93 & 0.77 & -0.57 & -1.67 & -17.02 \\
\hline
\end{tabular}

* Significant at the level of $0.05=2.01$

Table (3) that represents the significance differences between the teams of the 2010 and 2012 editions of the Africa Cup of Nations and the 2008 and 2012 editions of the European Soccer Championship in the effect of the substitute's entry on the variables of the technical performance of the team, showed that there are differences between the 2010 and 2012 editions of the Africa Cup of Nations and the 2008 and 2012 editions of the European Soccer Championship where (the substitute can get quickly in action in the game) in favor to the European Soccer Championship as the (t) value was (3.88), and this value is greater than the calculated $(\mathrm{t})$ value at the level of 0.05 .
The percentage of differences of the two cups and ranged between $(6.41 \%$ and $38.30 \%)$

Bret Myers (2011) also noted that the proceeding team's opponent would be offensive in order to achieve a goal and vice versa to keep the result, so most of the coaches involve highly experienced players who have the ability to get in action in the game quickly to exhaust the opposing team and to decrease their effectiveness (2:3)

The researcher believes that the European player possesses the experience that technically qualifies him to get in action in the game and execute his duties accurately. 
Table (4)

Significance differences between the teams of the 2010 and 2012 editions of the Africa Cup of Nations and the 2008 and 2012 editions of the European Soccer Championship in the effect of the substitute's entry on the situations of the game

\begin{tabular}{|c|c|c|c|c|c|c|c|c|c|}
\hline & & \multirow[t]{2}{*}{ Playing situations } & \multicolumn{2}{|c|}{$\begin{array}{l}\text { Africa Cup of } \\
\text { Nations } \\
\mathrm{N}=28\end{array}$} & \multicolumn{2}{|c|}{$\begin{array}{c}\text { European } \\
\text { Soccer } \\
\text { Championship } \\
\mathrm{N}=28\end{array}$} & \multirow[t]{2}{*}{$\begin{array}{l}\text { Difference } \\
\text { between } \\
\text { means }\end{array}$} & \multirow[t]{2}{*}{$\begin{array}{l}\text { Calculated } \\
\text { (t) value }\end{array}$} & \multirow[t]{2}{*}{$\begin{array}{l}\text { Percentage } \\
\text { of } \\
\text { difference } \\
\text { s } \%\end{array}$} \\
\hline & & & $X$ & $\pm \mathrm{P}$ & $\mathrm{X}$ & $\pm \mathrm{P}$ & & & \\
\hline \multirow{8}{*}{$\begin{array}{l}\text { The effect of the } \\
\text { substitute's entry on } \\
\text { the game }\end{array}$} & 1 & $\begin{array}{l}\text { Commitment of the substitute in } \\
\text { implementing the technical } \\
\text { instructions }\end{array}$ & 3.32 & 1.31 & 4.46 & 0.58 & -1.14 & $-4.23 *$ & $-34.41 *$ \\
\hline & 2 & $\begin{array}{l}\text { Physical superiority of the } \\
\text { substitute in the individual } \\
\text { offensive and defensive } \\
\text { situations }\end{array}$ & 3.50 & 1.35 & 4.36 & 0.83 & -0.86 & $-2.87 *$ & -24.49 \\
\hline & 3 & $\begin{array}{l}\text { Providing the team with the } \\
\text { ability to the defensive and } \\
\text { offensive tactical linking }\end{array}$ & 3.07 & 1.30 & 3.86 & 0.71 & -0.79 & $-2.81 *$ & -25.58 \\
\hline & 4 & $\begin{array}{c}\text { The ability to take advantage of } \\
\text { the positive time to achieve the } \\
\text { required result }\end{array}$ & 2.32 & 1.93 & 2.86 & 1.74 & -0.54 & -1.09 & -23.08 \\
\hline & 5 & $\begin{array}{c}\text { The ability to change or maintain } \\
\text { the result of the game }\end{array}$ & 2.14 & 2.32 & 2.89 & 2.08 & -0.75 & -1.27 & -35.00 \\
\hline & 1 & $\begin{array}{l}\text { Proficiency in implementing } \\
\text { free-kicks }\end{array}$ & 0.71 & 1.24 & 2.32 & 1.68 & -1.61 & $-4.07 *$ & -225.00 \\
\hline & 2 & $\begin{array}{l}\text { Proficiency in implementing } \\
\text { penalty kicks and penalties }\end{array}$ & 0.00 & 0.00 & 0.71 & 1.41 & -0.71 & & \\
\hline & 3 & $\begin{array}{l}\text { Proficiency in responding to the } \\
\text { penalty kicks }\end{array}$ & 0.07 & 0.38 & 0.00 & 0.00 & 0.07 & & \\
\hline
\end{tabular}

* Significant at the level of $0.05=2.01$

Table (4) that represents the differences between the teams of the 2010 and 2012 editions of the Africa Cup of Nations and the 2008 and 2012 editions of the European Soccer Championship in the effect of the substitute's entry on the game (commitment of the substitute in implementing the technical instructions, physical superiority of the substitute in the individual offensive and defensive situations, the ability to take advantage of the positive time to achieve the required result, and proficiency in implementing free-kicks) in favor to the 2008 and 2012 editions of the European Soccer Championship where the $(\mathrm{t})$ value ranged between $(2.81$ and 4.07), and this value is greater than the value calculated $(\mathrm{t})$ value at the level of 0.05 .

The percentage of differences of the two cups and ranged between $(23.08 \%$ and $225 \%)$

This conforms with Daniel Barbosa et al (2012) that the distinguished substitute's entry has its big effect in improving the physical performance of the team and thus improving the technical level $(3: 189)$, the researcher believes that the European substitute has the ability to comply with the instructions as a result of his discipline which he got used to in the European leagues. 
Table (5)

Significance differences between the teams of the 2010 and 2012 editions of the Africa Cup of Nations and the 2008 and 2012 editions of the European Soccer Championship in the effect of the substitute's entry on the game according to the goal of the substitution

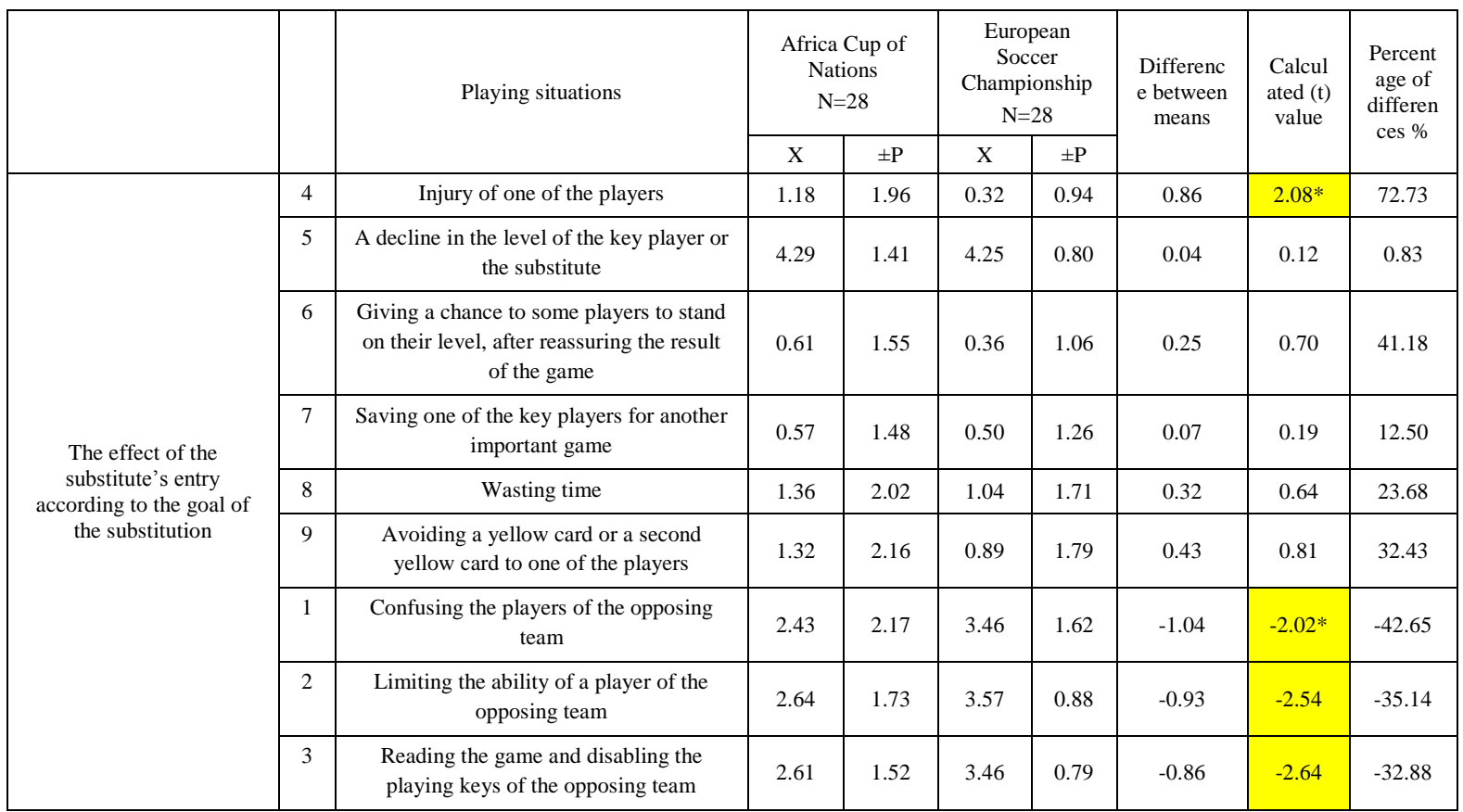

* Significant at the level of $0.05=2.01$

Table (5) that represents the significance differences between the teams of the 2010 and 2012 editions of the Africa Cup of Nations and the 2008 and 2012 editions of the European Soccer Championship in the effect of the substitute's entry on the game according to the goal of the substitution showed that there are differences between the mentioned tournaments (limiting the ability of a player of the opposing team, reading the game and disabling the playing keys of the opposing team, confusing the opponent's players) in favor to the European Soccer Championship and (injury of one of the players) regarding the Africa Cup of Nations, as the (t) value ranged between (2.02 and 2.64), and this value is greater than the calculated $(\mathrm{t})$ value at the level of 0.05 .
The percentage of differences of the two cups and ranged between $(0.83 \%$ and $72.73 \%)$.

This is consistent with what is noted by Bret Myers (2011) that the success of the substitute's entry is effective on improving the performance level reached (32\%) and the accuracy in choosing the substitute by the coach was (21\%), this is a good percentage according to the time in which the substitute participates. $(2: 3)$

The researcher believes that the substitute in Europe is not always less than the main player in technical level, so the coach may keep the substitute as a winning card and involve him in the right time to limit the ability of a certain player of the opposing team. 
Table (6)

Significance differences between the teams of the 2010 and 2012 editions of the Africa Cup of Nations and the 2008 and 2012 editions of the European Soccer Championship in the effect of the substitute's entry on the game according to the variables of the performance of the opposing team

\begin{tabular}{|c|c|c|c|c|c|c|c|c|c|}
\hline & & \multirow[t]{2}{*}{ Playing situations } & \multicolumn{2}{|c|}{$\begin{array}{l}\text { Africa Cup of } \\
\text { Nations } \\
\mathrm{N}=28\end{array}$} & \multicolumn{2}{|c|}{$\begin{array}{c}\text { European } \\
\text { Soccer } \\
\text { Championshi } \\
\mathrm{p} \\
\mathrm{N}=28\end{array}$} & \multirow[t]{2}{*}{$\begin{array}{c}\text { Difference } \\
\text { between } \\
\text { means }\end{array}$} & \multirow[t]{2}{*}{$\begin{array}{l}\text { Calculate } \\
\mathrm{d}(\mathrm{t}) \text { value }\end{array}$} & \multirow[t]{2}{*}{$\begin{array}{l}\text { Percentag } \\
\text { e of } \\
\text { difference } \\
\text { s \% }\end{array}$} \\
\hline & & & $\mathrm{X}$ & $\pm \mathrm{P}$ & $\mathrm{X}$ & $\pm \mathrm{P}$ & & & \\
\hline \multirow{6}{*}{$\begin{array}{l}\text { The effect of the substitute's } \\
\text { entry according to the } \\
\text { variables of the opposing } \\
\text { team's performance in the } \\
\text { game }\end{array}$} & 4 & $\begin{array}{l}\text { Forcing the opposing team to } \\
\text { change the plan }\end{array}$ & 1.18 & 1.59 & 2.68 & $\begin{array}{l}1.6 \\
3\end{array}$ & -1.50 & $-3.48 *$ & -127.27 \\
\hline & 5 & $\begin{array}{l}\text { Forcing the opposing team's } \\
\text { coach to change the situation of } \\
\text { one of the special players who has } \\
\text { tactical solutions }\end{array}$ & 0.36 & 1.06 & 0.57 & $\begin{array}{c}1.2 \\
9\end{array}$ & -0.21 & -0.68 & -60.00 \\
\hline & 6 & $\begin{array}{l}\text { Making a substitution as a } \\
\text { respond to another substitution } \\
\text { for the opposing team }\end{array}$ & 2.21 & 1.73 & 3.14 & $\begin{array}{c}0.9 \\
3\end{array}$ & -0.93 & $-2.50 *$ & -41.94 \\
\hline & 7 & $\begin{array}{l}\text { The substitute has high fitness so } \\
\text { the coach save him until fatigue } \\
\text { appears on the opposing team }\end{array}$ & 2.43 & 2.13 & 2.93 & $\begin{array}{c}1.8 \\
0\end{array}$ & -0.50 & -0.95 & -20.59 \\
\hline & 8 & $\begin{array}{l}\text { The substitute has high technical } \\
\text { abilities, tactical solutions and } \\
\text { experience so the coach save him } \\
\text { until fatigue appears on the } \\
\text { opposing team }\end{array}$ & 2.64 & 1.85 & 3.71 & $\begin{array}{c}0.9 \\
4\end{array}$ & -1.07 & $-2.73 *$ & -40.54 \\
\hline & 9 & $\begin{array}{l}\text { The ability to change the result of } \\
\text { the game due to the proficiency of } \\
\text { that }\end{array}$ & 1.39 & 2.25 & 1.75 & $\begin{array}{c}2.2 \\
0\end{array}$ & -0.36 & -0.60 & -25.64 \\
\hline
\end{tabular}

* Significant at the level of $0.05=2.01$

Table (6) that represents the significance differences between the teams of the 2010 and 2012 editions of the Africa Cup of Nations and the 2008 and 2012 editions of the European Soccer Championship in the effect of the substitute's entry on the game according to the variables of the performance of the opposing team showed that there are differences between 2010 and 2012 editions of the Africa Cup of Nations and the 2008 and 2012 editions of the European Soccer Championship (forcing the opposing team to change the plan, making a substitution as a respond to another substitution, the substitute has high technical abilities, tactical solutions and experience so the coach save him until fatigue appears on the opposing team) in favor to the European Soccer Championship as the $(\mathrm{t})$ value ranged between (2.50 and 3.48), and this value is greater than the calculated $(\mathrm{t})$ value at the level of 0.05 .
The percentage of differences of the two cups and ranged between $(20.59 \%$ and $127.27 \%)$.

This is consistent with what was noted by Bradley et al (2014) and Bernadette Woods \& Joanne Thatcher (2009) that substitution takes place when physical and technical levels decrease and for modification, so most of the European teams change the plan from time to time in accordance with the situations of the game and the opposing team $(4: 416)(1: 453)$

The researcher believes that the coach who has a substitute with high technical experience and fitness and can read the playing situations in the match while he still in the bench, as a result he has the ability to force the opponent to change the plan and stop the effective substitute to the opposing team or when fatigue appears on the opposing team, this players becomes the coach's winning card. 
Table (7)

Significance differences between the teams of the 2010 and 2012 editions of the Africa Cup of Nations and the 2008 and 2012 editions of the European Soccer Championship in the effect of the substitute's entry on the result of the game and the goal of achieving it

\begin{tabular}{|c|c|c|c|c|c|c|c|c|c|}
\hline & & \multirow[t]{2}{*}{ Playing situations } & \multicolumn{2}{|c|}{$\begin{array}{l}\text { Africa Cup of } \\
\text { Nations } \\
\mathrm{N}=28\end{array}$} & \multicolumn{2}{|c|}{$\begin{array}{c}\text { European } \\
\text { Soccer } \\
\text { Championshi } \\
\mathrm{p} \\
\mathrm{N}=28\end{array}$} & \multirow[t]{2}{*}{$\begin{array}{l}\text { Differenc } \\
\mathrm{e} \\
\text { between } \\
\text { means }\end{array}$} & \multirow[t]{2}{*}{$\begin{array}{l}\text { Calculate } \\
\mathrm{d}(\mathrm{t}) \\
\text { value }\end{array}$} & \multirow[t]{2}{*}{$\begin{array}{l}\text { Percentag } \\
\text { e of } \\
\text { differenc } \\
\text { es } \%\end{array}$} \\
\hline & & & $\mathrm{X}$ & $\pm \mathrm{P}$ & $\mathrm{X}$ & $\pm \mathrm{P}$ & & & \\
\hline \multirow{4}{*}{$\begin{array}{l}\text { The effect of the } \\
\text { substitute's entry on the } \\
\text { result of the game and its } \\
\text { aim }\end{array}$} & 1 & The player scores a goal and win & 1.57 & 2.33 & 1.14 & $\begin{array}{c}2.0 \\
5\end{array}$ & 0.43 & 0.73 & 27.27 \\
\hline & 2 & The player prevents scoring a goal & 0.61 & 1.59 & 1.00 & $\begin{array}{c}1.3 \\
6\end{array}$ & -0.39 & -0.99 & -64.71 \\
\hline & 3 & Making a goal & 0.36 & 1.31 & 0.96 & $\begin{array}{c}1.7 \\
7\end{array}$ & -0.61 & -1.46 & -170.00 \\
\hline & 4 & Improving the general ball control & 3.44 & 1.42 & 3.50 & $\begin{array}{c}0.8 \\
8\end{array}$ & -0.06 & -0.17 & -1.61 \\
\hline
\end{tabular}

* Significant at the level of $0.05=2.01$

Table (7) that represents the significance differences between the teams of the 2010 and 2012 editions of the Africa Cup of Nations and the 2008 and 2012 editions of the European Soccer Championship in the effect of the substitute's entry on the result of the game and the goal of achieving it that there were no significant differences between the cups in (all variables), as the $(\mathrm{t})$ value ranged between $(0.17$ and 1.46$)$, and this value is less than the calculated $(\mathrm{t})$ value at the level of 0.05 .

The percentage of differences of the two cups and ranged between $(1.61 \%$ and $170 \%)$.

The researcher noticed that the substitute played an important role in all of the tournaments which included the 2010 and 2012 editions of the Africa Cup of Nations and the 2008 and 2012 editions of the European Soccer Championship in affecting the result of the game and its objective in every single tournament respectively. This conforms to Paul Bradley et al (2014) who pointed that the substitute has a critical role in keeping the result of the game in a winning situation, as well as winning a several games for their teams in the premier league $(4: 422)$

\section{Conclusions:}

Out of the research results we conclude the following:

1- The substitute has an effect on the variable of technical performance through the substitute's ability to get in action in the game quickly in favor to the substitute.

2- There is a difference between the effect of the substitute on the game in the playing situations between the Africa Cup of Nations and the European Soccer Championship (commitment of the substitute in implementing the technical instructions, physical superiority of the substitute in the individual offensive and defensive situations, the ability to take advantage of the positive time to achieve the required result, and proficiency in implementing freekicks) in favor to the European Soccer Championship.

3- There is a difference between the effect of the substitute on the playing situations according to the goal of substitution between the teams of the 2010 and 2012 editions of the Africa Cup of Nations and the 2008 and 2012 editions of the European Soccer Championship in (limiting the ability of a player of the opposing team, reading the game and disabling the playing keys of the opposing team, confusing the opponent's players) in favor to the 2008 and 2012 editions of the European Soccer Championship and (injury of one of the players) regarding the 2010 and 2012 editions of the Africa Cup of Nations.

4- There is a difference between the effect of the substitute on the playing situations according to the variables of the performance of the opponent in the matches of the Africa Cup of Nations and the European Soccer Championship in (forcing the opposing team to change the plan, making a substitution as a respond to another substitution, the substitute has high technical abilities, tactical solutions and experience so the coach save him until fatigue appears on the opposing team) for the European Soccer Championship.

5- There is no difference between the Africa Cup of Nations and the European Soccer Championship in the effect of the substitute on the variables of the result of the game and the objective of it in (all variables). 


\section{Recommendations:}

Based on the results and conclusions, the researcher recommended the following:

1- Giving interest to the substitute during the training process.

2- Giving interest to the training program for the substitute during the season.

3- It is important not to deal with substitutes on the bench as they are supplements during the try match or just to complete the squad on the bench.

4- It is necessary to deal with the substitute as a key player to solve the puzzle of the opposing team at the right time.

5- Further research studies on the substitute in the Premier Egyptian league and the clubs of the first and second class football leagues.

\section{Arabic references:}

1- Hanafy Mahmoud Mokhtar (1995): Practical Application in Soccer, Cairo, Dar Al-Fikr Al-Araby

2- Mahmoud Bassiouny (1994): Psychological Preparation for the Players in Soccer, Cairo, Dar Al-Maaref

3- Mufty Ibrahim Hammad (1994): Innovation in the Physical, Technical and Tactical Preparation in Soccer, Dar Al-Fikr Al-Araby, Cairo
4- Moussa Khalid Ibrahim (2013): The Effect of the Substitute on the Level of Performance for the Palestinian Professional Soccer Players, unpublished master's thesis in physical education, Faculty of Graduate Studies, AlNajah National University

\section{Foreign references:}

1- Bernadette Woods, Joanne Thatcher (2009): A Qualitative Exploration of Substitutes Experiences in Soccer, Experiences in Soccer, The Sport Psychologist, 23, 451-469 Human Kinetics, Inc.

2- Bret R. Myers, (2011): A Proposed Decision Rule for the Timing of Soccer Substitutions, (C) 2011 American statistical association. all rights reserved DOI :10.1515,1559-0410.1349

3- Daniel Barbosa, Leonardo gomes, Rodrigo figueiredo, Joao battista, joao carlos, Luciano sales, danuso dias, Emerson salami (2012): Effect of player substitutions on The intinsty of second -half soccer, RBCDH,revista brasileiara de cineantropometria, E desempenho Humano

4- Paul S Bradley, Carlos Lago Peñas \& Ezequiel Rey (2014): Evaluation of the Match Performances of Substitution Players in Elite Soccer, Article in International journal of sports physiology and performance, May 2014, DOI: 10.1123/IJSPP.2013-0304 • Source: PubMed 